\title{
Immunomodulatory effect of mesenchymal stem cells on B cells
}

\section{Marcella Franquesa ${ }^{1,2}$ *, M. J. Hoogduijn ${ }^{1}$, O. Bestard ${ }^{2}$ and J. M. Grinyó ${ }^{2}$}

1 Department of Internal Medicine, Erasmus Medical Center, Rotterdam, Netherlands

${ }^{2}$ Department of Nephrology, Hospital de Bellvitge UB-IDIBELL, Barcelona, Spain

\author{
Edited by: \\ Frank J. M. F. Dor, Erasmus MC \\ University Medical Center Rotterdam, \\ Netherlands

\section{Reviewed by:} \\ Christian Jorgensen, INSERM, France \\ Alessandro Poggi, National Institute \\ for Cancer Research, Italy \\ *Correspondence: \\ Marcella Franquesa, Department of \\ Internal Medicine, Erasmus Medical \\ Center, P.O. Box 2040, 3000 CA \\ Rotterdam, Netherlands. \\ e-mail:m.franquesa@erasmusmc.nl
}

The research on $T$ cell immunosuppression therapies has attracted most of the attention in clinical transplantation. However, B cells and humoral immune responses are increasingly acknowledged as crucial mediators of chronic allograft rejection. Indeed, humoral immune responses can lead to renal allograft rejection even in patients whose cell-mediated immune responses are well controlled. On the other hand, newly studied B cell subsets with regulatory effects have been linked to tolerance achievement in transplantation. Better understanding of the regulatory and effector B cell responses may therefore lead to new therapeutic approaches. Mesenchymal stem cells (MSC) are arising as a potent therapeutic tool in transplantation due to their regenerative and immunomodulatory properties. The research on MSCs has mainly focused on their effects on T cells and although data regarding the modulatory effects of MSCs on alloantigen-specific humoral response in humans is scarce, it has been demonstrated that MSCs significantly affect B cell functioning. In the present review we will analyze and discuss the results in this field.

Keywords: MSC, B cells, humoral rejection, chronic allograft rejection, immunomodulation

\section{INTRODUCTION}

$\mathrm{B}$ cells are a major cell type involved in adaptive immune responses, specialized in antigen presentation and antibody production. The balance between the different $\mathrm{B}$ cell subsets has been identified as an important factor for graft outcome. On one hand, effector B cells generate humoral rejection and pre-formed donor-specific antibodies (DSA) against human leukocyte antigen (HLA)-I or HLA-II that have been correlated to worst graft outcome. On the other hand, pro-tolerogenic B cell subsets have been identified. An increase in immature transitional and naïve $B$ cells has been related to tolerance (Liu et al., 2007) and increased B cell numbers and a differential expression of $B$ cell-related genes were observed in the peripheral blood of a small cohort of tolerant kidney and liver transplant patients compared to stable patients under immunosuppression or to healthy controls (Newell et al., 2010; Sagoo et al., 2010).

Mesenchymal stem cells are multipotent stromal cells localized in virtually every tissue. They are characterized by their adherence to plastic, the expression of surface markers as CD73, CD90, and CD105 among others and the lack of expression of typical hematopoietic markers as CD45 and CD11b (Roemeling-van Rhijn et al., 2012). They also show differentiation potential into different cell lineages under controlled culture conditions. MSCs have been considered as naturally immunoprivileged cells due to low expression of HLA and co-stimulatory molecules in unstimulated conditions and although it is now well-known that under inflammatory stimulation they can express both HLA-I and HLAII it is also known that under this condition they exert more potent immunosuppressive actions (Crop et al., 2010).

The effect of MSCs on effector and regulatory T cells has been widely studied (Duffy et al., 2011a) and there is also evidence for a suppressive role of MSCs on natural killer (NK) cells (Spaggiari et al., 2008), inhibition of dendritic cells (DCs) maturation (Spaggiari et al., 2009), and alternative activation of macrophages leading to an anti-inflammatory phenotype (Francois et al., 2012). The interaction between MSCs and B cells is gaining interest but data is still scarce and controversial. Here we review the available data on the immunomodulatory actions of MSCs on B cells.

\section{B CELLS IN TRANSPLANTATION}

$\mathrm{T}$ cell-mediated rejection is together with antibody-mediated rejection the main cause of graft loss. Although research on T cell immunosuppressive therapies has efficiently improved the incidence of acute cellular rejection, long-term allograft survival remains challenged by chronic rejection. Activated B cells have been found to play a significant role on long-term allograft function. Their ability to present antigen to $\mathrm{T}$ cells via the indirect pathway and the generation of DSAs are emerging as the major mediators of allograft rejection. Pre-existing DSAs in the allograft recipient mediate hyperacute and acute-antibody-mediated rejection while the presence of de novo DSAs (specific for HLA and non-HLA) in recipients compromises long-term allograft survival (Redfield et al., 2011). Furthermore, it has been observed that CD8 and $\mathrm{CD} 4 \mathrm{~T}$ cell memory is impaired when the antigen presenting function of B cells is absent (Ng et al., 2010). This finding would support the idea of a beneficial effect of $B$ cell depletion at the time of transplantation to impair $\mathrm{T}$ cell mediated alloresponses.

However, there is increasing evidence for a tolerogenic role of specific B cell subsets. Naïve B cells have been shown to stimulate the development of regulatory $\mathrm{T}$ cells by antigen presentation to naïve $\mathrm{T}$ cells (Reichardt et al., 2007). And more recently, increased expression levels of B cell genes were found 
in peripheral blood of kidney transplant patients that spontaneously became tolerant (Newell et al., 2010; Sagoo et al., 2010). The three main genes with predictive value for discerning tolerant from non-tolerant (IGKV4-1, IGLL1, and IGKV1D-13) are expressed by transitional B cells, which are considered to be tolerogenic. Moreover, there is evidence of a subset of $B$ cells with anti-inflammatory properties and the ability to secrete IL10, which down-regulation is known to be involved in the development of autoimmune diseases (Mauri and Bosma, 2011) and in solid organ transplantation there is preliminary evidence for their presence in immunosuppressive free kidney transplant patients (Le Texier et al., 2011).

The use of $\mathrm{B}$ cell directed monoclonal antibodies (antiCD20, Rituximab), antibody depleting strategies (plasmapheresis), plasma cell depleting agents (anti-proteasome, Bortezomib), or complement-inhibitor agents (Eculizumab) have been reported to be efficient in promoting graft survival (Rocha et al., 2003; Tyden et al., 2009; Walsh et al., 2012). It is however still controversial which approach is the best to avoid humoral rejection without compromising regulatory mechanisms.

\section{IMMUNOMODULATORY EFFECT OF MSCs IN TRANSPLANTATION}

T cells, as key initiators and mediators of transplant rejection, have been the main target to prove the immunomodulatory potential of MSCs. Multiple studies have demonstrated that MSCs inhibit effector $\mathrm{T}$ cell proliferation and cytokine release through mechanisms that are cell-contact-dependent (PD-L1, Augello et al., 2005; B7-H4, Xue et al., 2010; ICAM1; VCAM1, Ren et al., 2010) and contact-independent (IDO, Ge et al., 2010; $\mathrm{PGE}_{2}$, Najar et al., 2010; Duffy et al., 2011b; HLA-G, Selmani et al., 2009; TGF $\beta$, Liu et al., 2012; galectins, Sioud, 2011). In vivo models have shown that MSCs have an indirect effect on T cell activation by inhibition of maturation of DCs. Injected MSCs prevent DCs maturation (Spaggiari et al., 2009) and their migration to lymph nodes by down-regulating CCR7 expression, thus inhibiting $\mathrm{T}$ cell priming (Chiesa et al., 2011). MSC-exposed DCs have also the ability to promote Tregs induction (Ge et al., 2009). MSCs posses also the ability to induce Tregs directly via the production of TGF $\beta$, $\mathrm{PGE}_{2}$ together with cell-contact as key factors. In vivo, FoxP3 ${ }^{+}$ Treg generation has been associated with IDO expression by MSC (English et al., 2009). This factor is produced by MSCs under IFN $\gamma$ conditioning (Croitoru-Lamoury et al., 2011) and is essential to achieve allograft tolerance in an experimental kidney transplantation model (Ge et al., 2010). It appears that MSCs under inflammatory conditions act as super-regulators on T cells inhibiting the effector responses and enhancing the regulation inducing Tregs.

Of note, these actions are not only relegated to the experimental and in vitro setting as the applicability of injected MSCs as induction therapy in human kidney transplantation has been recently proved. Injection of autologous MSCs at the moment of transplantation and 2 weeks post-transplantation resulted in lower incidence of acute rejection, decreased risk of opportunistic infection and better estimated renal function at 1 year compared to anti-IL2 receptor antibody (Basiliximab) induction therapy (Tan et al., 2012).

\section{EFFECT OF MSCS ON B CELLS IN VITRO}

To the moment, the few published papers studying the effect of MSCs on B cells proliferation, differentiation, and function show disparity in their approaches and results. The different results among the groups might be explained by the different starting $B$ cell population (purity and isolation method) and the stimuli used to trigger B cell differentiation and proliferation. MSC: B cell ratio is also an important point, as the most effective ratios used are very high and it is hardly observed a dose dilution effect, contrarily to what happens with the immunosuppressive effect of MSCs on T cells (Hoogduijn et al., 2008).

\section{CELL SOURCE AND ISOLATION METHOD}

If we refer to in vitro data (Table 1), the main starting difference of those studies is the B cell isolation method. On one hand, some authors decided for a more "physiological" model by using a B cell enriched system in which we can still find T helper cells (in different proportion depending on the depleting technique and the source used) and other mononuclear cells found in peripheral blood or spleen (Rasmusson et al., 2007; Comoli et al., 2008). On the other hand, some authors use CD19 positive selection to start with a pure B cell population (Corcione et al., 2006; Tabera et al., 2008; Traggiai et al., 2008), or a CD43 depleted population to have an isolated "untouched" non-activated B cell population to start with (Asari et al., 2009; Schena et al., 2010). The purity of the starting population and the stimuli used to trigger B cell proliferation and differentiation are key factors in determining the effect of MSCs on B cells.

Of note, the source of MCS used in the various studies is bone marrow and the use of allogeneic or autologous MSCs does not seem to affect the interaction between MSC and B cells (Comoli et al., 2008).

The first key study to understand the role of MSC on B cells, on a non-purified starting population, was performed by Comoli et al. (2008). The exposure of enriched B cell populations to irradiated third party PBMCs led to an increase in immunoglobulin (Ig) production that was abrogated by the addition of MSCs. Interestingly the effect exerted by MSCs was abolished by the addition of anti-CD40 and IL10 indicating that MSCs suppression of Ig production was produced by $\mathrm{T}$ help suppression rather than by a direct effect on B cells. This is in tune with Rasmusson et al. (2007) who showed that under strong stimulation of mononuclear cell fraction (non-purified B cells), MSCs inhibited the Ig secretion. However, the same cells without or under mild polyclonal stimulation increased their IgG production in the presence of MSCs (Rasmusson et al., 2007).

However, when the effect of MSCs is studied on purified B cells (or B cell subsets) the effect is diverse depending on the stimuli used to induce proliferation and/or differentiation.

\section{CELL STIMULATION}

The activation of naïve B cells requires three signals: B cell receptor (BCR) activation (via anti-Ig), T cell co-stimulatory help (via CD40/CD40L), and appropriate cytokines or toll-like receptor (TLR) activation (microbial products, CpG, dsRNA), while memory B cells can be activated in the absence of BCR stimulation and triggered via stimulation of TLR or bystander T cell help only 
Table 1 | Effect of MSCs on B cells in vitro.

\begin{tabular}{|c|c|c|c|c|c|}
\hline $\begin{array}{l}\text { Species and } \\
\text { model }\end{array}$ & B cell isolation & $\begin{array}{l}\text { B: MSC } \\
\text { ratio }\end{array}$ & B cell stimuli & Effect of MSCs & Reference \\
\hline \multicolumn{6}{|l|}{ MICE } \\
\hline $\begin{array}{l}\text { Mouse B6 and } \\
\text { CCR2- }\end{array}$ & $\begin{array}{l}\text { Spleen sorted } \\
\text { CD19-CD138 } \\
\text { plasma cells }\end{array}$ & $1: 1$ & rOVA & $\begin{array}{l}\text { Inhibition of Ig production by a cleaved form of CCL2 } \\
\text { secreted by MSCs. }\end{array}$ & $\begin{array}{l}\text { Rafei et al. } \\
\text { (2008) }\end{array}$ \\
\hline $\begin{array}{l}\text { Mouse } \\
\mathrm{C} 57 \mathrm{BI} / \mathrm{g}\end{array}$ & $\begin{array}{l}\text { Spleen CD43 } \\
\text { depletion }\end{array}$ & $\begin{array}{l}2: 1 \\
5: 1 \\
10: 1\end{array}$ & $\begin{array}{l}\text { LPST cell } \\
\text { dependent/ } \\
\text { independent } \\
\text { in vivo }\end{array}$ & $\begin{array}{l}\text { Inhibition of Plasma cells (Blimp-1+) induced by LPS. } \\
\text { Suppression of B cell proliferation but do not induce } \\
\text { plasma cell apoptosis. B cell differentiation inhibition } \\
\text { is cell-contact-independent (also not CCL2, IL10, } \\
\text { TGF } \beta \text {, or IDO). }\end{array}$ & $\begin{array}{l}\text { Asari et al. } \\
(2009)\end{array}$ \\
\hline $\begin{array}{l}\text { Mouse } \\
\text { NZBxNZW F1 }\end{array}$ & $\begin{array}{l}\text { Spleen, BM, kidney } \\
\text { CD138+ plasma } \\
\text { cells isolation }\end{array}$ & $\begin{array}{l}1: 1 \\
1: 5\end{array}$ & OVA & $\begin{array}{l}\text { Coculture MSCs increase survival and function of } \\
\text { plasma cells leading to increased lgG production. }\end{array}$ & $\begin{array}{l}\text { Youd et al. } \\
(2010)\end{array}$ \\
\hline \multicolumn{6}{|l|}{ HUMANS } \\
\hline $\begin{array}{l}\text { Human healthy } \\
\text { volunteer }\end{array}$ & $\begin{array}{l}\text { PBT cell } \\
\text { depleted }+ \text { CD19+ } \\
\text { positive selection } \\
\text { MACS }\end{array}$ & $\begin{array}{l}1: 1 \\
1: 2\end{array}$ & $\begin{array}{l}\mathrm{CpG}+\mathrm{rCD} 40 \mathrm{~L} \\
+ \text { anti-lg + IL2 } \\
+ \text { IL4 } \pm \text { IL10 }\end{array}$ & $\begin{array}{l}\text { Inhibition of proliferation (not apoptosis) by arrest of } \\
\text { cell cycle G0/G1. Mediated by soluble factors. } \\
\text { Inhibition of IgG, IgA, IgM secretion. } \\
\text { Inhibition of homig molecules CXCR4, CXCR5, CCR7, } \\
\text { and chemotaxis to CXCL12, CXCL13. }\end{array}$ & $\begin{array}{l}\text { Corcione } \\
\text { et al. (2006) }\end{array}$ \\
\hline $\begin{array}{l}\text { Human healthy } \\
\text { volunteer and } \\
\text { highly } \\
\text { sensitized } \\
\text { patients }\end{array}$ & $\begin{array}{l}\text { PB partial depletion } \\
\text { CD4 and full } \\
\text { depletion CD8 } \\
\text { MACS }\end{array}$ & $\begin{array}{l}4: 1 \\
20: 1\end{array}$ & $\begin{array}{l}\mathrm{MLC} \pm \mathrm{CD} 40 \\
\text { agonist }+\mathrm{IL} 10\end{array}$ & $\begin{array}{l}\text { MSCs inhibit IgG, IgA, IgM production induced in } \\
\text { MLC (different ratios and allogeneic or syngeneic } \\
\text { MSCs have same effect). Sensitized patients allo-sera } \\
\text { induce ADCC but supernatant of MLC + MSC do not } \\
\text { induce ADCC. In the presence of agonist } \\
\text { CD40 + IL10, MSCs have no effect on Ig reduction and } \\
\text { in transwell the effect is not lost. }\end{array}$ & $\begin{array}{l}\text { Comoli et al. } \\
\text { (2008) }\end{array}$ \\
\hline $\begin{array}{l}\text { Human healthy } \\
\text { volunteer }\end{array}$ & $\begin{array}{l}\text { Buffy Coat } \mathrm{CD} 19^{+} \\
\text {and } \mathrm{CD}^{+} \text {selection } \\
\text { MACS }\end{array}$ & $\begin{array}{l}5: 1 \\
10: 1\end{array}$ & $\begin{array}{l}\mathrm{CpG}+\text { anti- } \\
\lg \pm \mathrm{CD} 40 \mathrm{~L} \\
+\mathrm{IL} 4\end{array}$ & $\begin{array}{l}\text { Promotion of B cell proliferation and viability but under } \\
\text { highly proliferative conditions, MSCs arrest B cell } \\
\text { cycle in G0/G1. Inhibit Plasma cells induced by pDCs } \\
\text { mediated by ERK } 1 / 2 \text { and p38 phosphorylation. }\end{array}$ & $\begin{array}{l}\text { Tabera et al. } \\
\text { (2008) }\end{array}$ \\
\hline
\end{tabular}


Table 1 | Continued

\begin{tabular}{|c|c|c|c|c|c|}
\hline $\begin{array}{l}\text { Species and } \\
\text { model }\end{array}$ & B cell isolation & $\begin{array}{l}\text { B: MSC } \\
\text { ratio }\end{array}$ & B cell stimuli & Effect of MSCs & Reference \\
\hline $\begin{array}{l}\text { Human healthy } \\
\text { and SLE }\end{array}$ & $\begin{array}{l}\text { PB CD } 19^{+} \text {selection } \\
\text { MACS + subsets } \\
\text { sorting }\end{array}$ & $1: 1$ & $\begin{array}{l}\text { CpG + IL2 } \\
\pm \text { CD40L } \\
+ \text { anti-lg }\end{array}$ & $\begin{array}{l}\text { Induction of survival and proliferation of transitional, } \\
\text { naïve, IgM memory, and switch memory subsets } \\
\text { with/out stimulation. Up-regulation of CD38 and IGM } \\
\text { but naïve B cells do not increase IgA and IgG. } \\
\text { Cell-contact-dependent effect. Enhancement of } \\
\text { survival of SLE patient B cell subsets, increase CD38 } \\
\text { expression and IgM and IgG secretion. }\end{array}$ & $\begin{array}{l}\text { Traggiai et al. } \\
\text { (2008) }\end{array}$ \\
\hline
\end{tabular}

Summary of the published works on the effect of MSCs on B cells in vitro. In all cases the source of MSCs is bone marrow. PWM, Pokeweed mitogen; OVA, ovalbumin; LPS, lipopolysaccharide; BM, bone marrow; PB, peripheral blood; MACS, magnetic cell sorting technology; CMV, cytomegalovirus; VZV, varicella zoster virus; MNCs, mononuclear cells; MLC, mixed lymphocyte culture.

(Lanzavecchia et al., 2006). MSC may have a role in modulating some of these $\mathrm{B}$ cell activating pathways.

Among the studies that isolated pure B cells and exposed them to different stimuli to analyze the effect of MSCs we find diverse results. Although MSC were shown to increase the viability of $\mathrm{B}$ cells (Tabera et al., 2008), they arrest them in $\mathrm{G}_{0} / \mathrm{G}_{1}$ (Corcione et al., 2006; Tabera et al., 2008) and inhibit their differentiation into plasma cells and subsequent Ig formation. This effect has been shown to be cell-contact-independent (Asari et al., 2009) or indirect through inhibition of pDCs induced B cell maturation (Tabera et al., 2008). Contrarily, some authors (Augello et al., 2005; Schena et al., 2010) found PD-1/PD-L1 interaction and the inhibition of pathways downstream the BCR (Schena et al., 2010) to be responsible for B cell inhibition by MSC. However, Schena et al. (2010) observed that pre-exposure of MSCs to IFN $\gamma$ was mandatory for their suppressive effect on B cells, similar to their effect on T cells (Crop et al., 2010). These studies on isolated B cells were performed in the presence of stimuli targeting the three signals for B cell activation, suggesting a role of MSCs directly on $B$ cells besides their effect on Thelper cells (contrarily to what was observed in studies using mixed starting population).

In contrast to activated $\mathrm{B}$ cells, isolated naïve, transitional, and memory B cell subsets exposed to MSCs increased their survival and proliferation (Traggiai et al., 2008). MSCs synergize with TLR stimuli and IL2, with or without T cell help (CD40L or antiCD40) and BCR mediated stimulation by inducing proliferation and differentiation into plasma cells. This effect was shown to be contact-dependent although some of the factors released by MSCs are important to modulate this effect.

In this setting, the effect of the stimuli on MSCs should be also taken into account. It has been proved that MSCs express TLRs (DelaRosa and Lombardo, 2010), and their activation promote mainly a different cytokine secretion. MSC stimulated with CpG (one of the main stimuli used in B cell activation that acts through TLR9) produce IL6. This cytokine stimulates B cell proliferation (Friederichs et al., 2001) and could be an explanation for the MSC induction of naïve B cell proliferation under TLR9 stimulation in the absence of BCR triggering (Traggiai et al., 2008).

All these studies give a hint on a potential dual effect of MSCs on B cells. While in the enriched system the effect of MSCs on B cells appear to be by-passed by their immunosuppressive action on T cells, in an activated pure B cell population MSCs efficiently arrest or increase the proliferation depending on the potency of the stimuli on B cells but also on MSCs. Both cell-contact-dependent and independent factors are involved.

\section{EFFECT OF MSCs ON PLASMA CELLS}

Mesenchymal stem cells inhibit plasma cell formation induced by allostimulation (Comoli et al., 2008), by LPS (Asari et al., 2009) or by plasmatic DCs (Tabera et al., 2008) and subsequent Ig production (Corcione et al., 2006; Rasmusson et al., 2007). The mechanisms of action described to be involved are cell-contactindependent (alternatively cleaved CCL2 Rafei et al., 2008) or dependent (PD-1/PD-L1 interaction, Schena et al., 2010).

However, we also find some disparity in the results obtained in vitro, as some authors observed and increased differentiation into plasma cells with increased Ig production (Traggiai et al., 2008) along with a better survival and function (Youd et al., 2010). This observation is reflected in in vivo systemic lupus erythomatosus (SLE) models treated with MSCs.

\section{EFFECT OF MSCs ON B CELLS IN VIVO}

Similar to the controversial in vitro effects of MSC on B cells, there are contradictory reports on the effects of MSC on B cells in animal models.

Different groups have approached the treatment of a SLE model with MSCs. A single injection of human BM-MSCs combined with cyclophosphamide (CTX) increased survival, decreased proteinuria, and reduced the levels of circulating anti-dsDNA IgG in a MRL/Lpr mice model (Zhou et al., 2008), and similar results were obtained in NZBxNZW F1 mice injected preventively with adipose tissue MSCs every 2 weeks for 54 weeks although this protective effect was lost when the animals were treated after the onset of the disease (Choi et al., 2012). This late treatment does not prevent from developing anti-dsDNA IgG or proteinuria, neither increases the survival of the treated animals but it decreases lymphocytic infiltration, glomerular proliferation, and immune complex deposition (Schena et al., 2010). Contrarily, the use of mouse allogeneic MSCs in this model, increases serum anti-dsDNA antibodies and the glomerular deposition of IgG, along with higher interstitial fibrosis and inflammation and protein casts in the kidney when compared to CTX treatment (Youd et al., 2010). Of note the 
numbers of $\mathrm{IgG}^{+}$plasma cells in the bone marrow of MSC treated mice are also increased (Table 2 ).

In the transplantation setting, we (Franquesa et al., 2012) and others (Ge et al., 2009) have demonstrated that MSCs injection can significantly reduce levels of allospecific circulating antibodies and intragraft allospecific IgG deposits (Ge et al., 2009) leading to long-term graft acceptance.

\section{INDUCTION OF B CELL RESPONSES BY ALLO-MSC}

Despite the low immunogenicity that MSCs are supposed to exert (low HLA class I and negative for HLA class II in unstimulated conditions), there is evidence that MSC may be capable of inducing an adaptive immune response (Nauta et al., 2006; Sbano et al., 2008). Therefore it is still a matter of debate whether allogeneic MSCs exert a humoral response in the recipient.

In rats a single injection of allogeneic MSC $\left(1 \times 10^{6}\right.$ cells/animals $)$ induced substantial alloantibody production (IgG1, IgG2) in contrast to syngeneic cells injection in an immunocompetent host (Schu et al., 2011). Also immunocompetent non-human primates (baboons) injected with two doses of allogeneic MSCs $\left(5 \times 10^{6}\right.$ cells $/ \mathrm{kg}$ body weight) developed alloantibodies (Beggs et al., 2006). Contrarily, in a clinical study with 12 patients which were treated with MSCs $\left(0.8-2.0 \times 10^{6}\right.$ cells $/ \mathrm{kg}$ body weight) after hematopoietic stem cell (HSC) transplantation, none of them developed anti-MSC antibodies (Sundin et al., 2007). And our own experience with a single injection of third party
MSCs $\left(0.5 \times 10^{6} / 300 \mathrm{~g}\right.$ body weight $)$ in a rat kidney transplantation model is that the injected animals do not develop specific anti-MSCs antibodies while they do increase antibody levels against the third party when they are injected with the full fraction of bone marrow mononuclear cells (Franquesa et al., 2012).

Those studies reflect some disparity of humoral response directed against the injected MSCs that could be explained by the source of MSCs (allo- vs. syngeneic), the number of injected cells, the number of injections, the route of administration or concurrent immunosuppression used. More in vivo studies need to be done to develop safe long-term protocols for the clinical setting.

\section{CONCLUSION}

The role of B cells in transplantation is multifaceted due to the opposed roles of different B cell subsets in tolerance and rejection. This enlightens the need for more refined immunosuppressive regimens to treat humoral rejection without compromising the effect of the pro-tolerogenic B cell subsets, namely transitional and regulatory $\mathrm{B}$ cells.

Mesenchymal stem cells have proven immunomodulatory properties, suppressing inflammatory cell (effector T cells, DCs, inflammatory macrophages) functions, and differentiation and increasing or synergizing with regulatory cells such as Tregs.

Their effect on B cells has been scarcely studied and although the results obtained are contradictory so far, it seems clear there

Table 2 | Effect of MSCs on B cells in vivo.

\begin{tabular}{|c|c|c|c|c|c|}
\hline Model & Species & MSC source & MSC dose & Effect of MSCs & Reference \\
\hline SLE & $\begin{array}{l}\text { Mouse female } \\
\text { MRL/Lpr }\end{array}$ & BM human & $1 \times 10^{6} /$ mice & $\begin{array}{l}\text { MSCs alone or combined with Cyclophosphamide (CTX) } \\
\text { reduce serum creatinine levels and C3 deposition compared } \\
\text { to CTX alone. CTX+ MSC reduce circulating dsDNA } \\
\text { antibodies. }\end{array}$ & Zhou et al. (2008) \\
\hline $\begin{array}{l}\text { Heart } \\
\text { allograft }\end{array}$ & $\begin{array}{l}\text { Mouse } \\
\text { C57BL/6 } \\
\text { BALB/c C3H }\end{array}$ & $\mathrm{BM}$ & $1 \times 10^{6} / \mathrm{mice}$ & $\begin{array}{l}\text { Inhibition of intragraft and circulating alloreactive antibody } \\
\text { levels. In combination with rapamycin induce tolerance. }\end{array}$ & Ge et al. (2009) \\
\hline SLE & $\begin{array}{l}\text { Mouse } \\
\text { C57BI/g }\end{array}$ & $\begin{array}{l}\text { BM } \\
\text { conditioned } \\
\text { medium }\end{array}$ & $\begin{array}{l}\text { Conditioned } \\
\text { medium }\end{array}$ & $\begin{array}{l}\text { Suppression of antigen specific lgM and lgG1 secretion in } \\
\text { immunized mice with T cell-dependent and -independent } \\
\text { effect }\end{array}$ & Asari et al. (2009) \\
\hline SLE & $\begin{array}{l}\text { Mouse } \\
\text { NZBxNZW F1 }\end{array}$ & $\begin{array}{l}\text { BM C57BL/6J } \\
\text { mice }\end{array}$ & $\begin{array}{l}3 \text { Injections } \\
1.25 \times 10^{6}\end{array}$ & $\begin{array}{l}\text { Injections of MSC in SLE mice has no effect on lgG dsDNA, } \\
\text { proteinuria and survival, but improves glomerular } \\
\text { proliferation, lymphocytic infiltration, and lgG immune } \\
\text { complex deposition. }\end{array}$ & Schena et al. (2010 \\
\hline SLE & $\begin{array}{l}\text { Mouse } \\
\text { NZBxNZW F1 }\end{array}$ & $\begin{array}{l}\text { BM Allogeneic } \\
\text { Balb/C }\end{array}$ & $\begin{array}{l}1 \times 10^{6} \\
\text { Bi-weekly for } \\
18 \text { or } 7 \text { weeks }\end{array}$ & $\begin{array}{l}\text { MSC enhance autoantibody production, pathology and } \\
\text { proteinuria. }\end{array}$ & Youd et al. (2010) \\
\hline SLE & $\begin{array}{l}\text { Mouse } \\
\text { NZBxNZW F1 }\end{array}$ & AT human & $\begin{array}{l}28 \text { Injections } \\
5 \times 10^{5}\end{array}$ & $\begin{array}{l}\text { Higher survival, improvement of histologic, and serologic } \\
\text { abnormalities and immunologic function and decreased } \\
\text { proteinuria. Anti-dsDNA antibodies and BUN decreased. } \\
\text { GM-CSF, IL4, and IL10 increase. Increase of Tregs } \\
\text { proportion. Early injections have best results than late } \\
\text { treatment. }\end{array}$ & Choi et al. (2012) \\
\hline
\end{tabular}

Summary of the published works on the effect of MSCS on B cells in vivo. BM, bone marrow; SLE, systemic lupus erythematosus; AT, adipose tissue. 
is a close interaction between MSC and B cells. It appears that this interaction occurs partly through the modulation of $\mathrm{T}$ cell help by MSCs, but also in the absence of helper cells MSCs can inhibit activated B cells. The study of this threesome relation is of special interest in the transplantation setting. Another interesting point that remains to be studied is the potential of MSCs to induce pro-tolerogenic B cell subsets that have themselves proved immunomodulatory properties.

\section{REFERENCES}

Asari, S., Itakura, S., Ferreri, K., Liu, C. P., Kuroda, Y., Kandeel, F., and Mullen, Y. (2009). Mesenchymal stem cells suppress B-cell terminal differentiation. Exp. Hematol. 37, 604.

Augello, A., Tasso, R., Negrini, S. M., Amateis, A., Indiveri, F., Cancedda, R., and Pennesi, G. (2005). Bone marrow mesenchymal progenitor cells inhibit lymphocyte proliferation by activation of the programmed death 1 pathway. Eur. J. Immunol. 35, 1482.

Beggs, K. J., Lyubimov, A., Borneman, J. N., Bartholomew, A., Moseley, A., Dodds, R., Archambault, M. P., Smith, A. K., and McIntosh, K. R. (2006). Immunologic consequences of multiple, high-dose administration of allogeneic mesenchymal stem cells to baboons, Cell Transplant. 15, 711.

Chiesa, S., Morbelli, S., Morando, S., Massollo, M., Marini, C., Bertoni, A., Frassoni, F., Bartolome, S. T., Sambuceti, G., Traggiai, E., and Uccelli, A. (2011). Mesenchymal stem cells impair in vivo T-cell priming by dendritic cells. Proc. Natl. Acad. Sci. U.S.A. 108, 17384.

Choi, E. W., Shin, I. S., Park, S. Y., Park, J. H., Kim, J. S., Yoon, E. J., Kang, S. K., Ra, J. C., and Hong, S. H. (2012). Reversal of serologic, immunologic, and histologic dysfunction in mice with systemic lupus erythematosus by long-term serial adipose tissue-derived mesenchymal stem cell transplantation. Arthritis Rheum. 64, 243.

Comoli, P., Ginevri, F., Maccario, R., Avanzini, M. A., Marconi, M., Groff, A., Cometa, A., Cioni, M., Porretti, L., Barberi, W., Frassoni, F., and Locatelli, F. (2008). Human mesenchymal stem cells inhibit antibody production induced in vitro by allostimulation. Nephrol. Dial. Transplant. 23, 1196.

Corcione, A., Benvenuto, F., Ferretti, E., Giunti, D., Cappiello, V., Cazzanti, F., Risso, M., Gualandi, F., Mancardi, G. L., Pistoia, V., and Uccelli, A. (2006). Human mesenchymal stem cells modulate B-cell functions. Blood 107, 367.
Croitoru-Lamoury, J., Lamoury, F. M., Caristo, M., Suzuki, K., Walker, D., Takikawa, O., Taylor, R., and Brew, B. J. (2011). Interferon-gamma regulates the proliferation and differentiation of mesenchymal stem cells via activation of indoleamine 2,3 dioxygenase (IDO). PLoS ONE 6, el4698. doi:10.1371/journal.pone.0014698

Crop, M. J., Baan, C. C., Korevaar, S. S., Ijzermans, J. N., Pescatori, M., Stubbs, A. P., van Ijcken, W. F., Dahlke, M. H., Eggenhofer, E., Weimar, W., and Hoogduijn, M. J. (2010). Inflammatory conditions affect gene expression and function of human adipose tissue-derived mesenchymal stem cells. Clin. Exp. Immunol. 162, 474.

DelaRosa, O., and Lombardo, E. (2010). Modulation of adult mesenchymal stem cells activity by toll-like receptors: implications on therapeutic potential. Mediators Inflamm. 2010, 865601.

Duffy, M. M., Ritter, T., Ceredig, R., and Griffin, M. D. (2011a). Mesenchymal stem cell effects on T-cell effector pathways. Stem Cell Res. Ther. 2, 34.

Duffy, M. M., Pindjakova, J., Hanley, S. A., McCarthy, C., Weidhofer, G. A., Sweeney, E. M., English, K., Shaw, G., Murphy, J. M., Barry, F. P., Mahon, B. P., Belton, O., Ceredig, R., and Griffin, M. D. (2011b). Mesenchymal stem cell inhibition of T-helper 17 cell- differentiation is triggered by cell-cell contact and mediated by prostaglandin E2 via the EP4 receptor. Eur. J. Immunol. 41, 2840.

English, K., Ryan, J. M., Tobin, L., Murphy, M. J., Barry, F. P., and Mahon, B. P. (2009). Cell contact, prostaglandin $\mathrm{E}(2)$ and transforming growth factor beta 1 play nonredundant roles in human mesenchymal stem cell induction of CD4+ CD25(High) forkhead box P3+ regulatory $\mathrm{T}$ cells. Clin. Exp. Immunol. 156, 149. M., and Galipeau, J. (2012). Human MSC suppression correlates with cytokine induction of indoleamine 2,3-dioxygenase and bystander M2 macrophage differentiation. Mol. Ther. 20, 187.
Francois, M., Romieu-Mourez, R., Li,
The potential of MSCs in B cell immunomodulation appears to be promising and not fully understood. The advent of new and well designed studies can give important insights to fully picture the therapeutic role of MSCs in B cell mediated rejection.

\section{ACKNOWLEDGMENTS}

Marcella Franquesa is in receipt of an ERA-EDTA/EMBO fellowship.

Franquesa, M., Herrero, E., Torras, J., Ripoll, E., Flaquer, M., Goma, M., Lloberas, N., Anegon, I., Cruzado, J. M., Grinyo, J. M., and HerreroFresneda, I. (2012). Mesenchymal stem cell therapy prevents IFTA in a rat kidney allograft model. Stem Cells Dev. PMID:22494435. [Epub ahead of print].

Friederichs, K., Schmitz, J., Weissenbach, M., Heinrich, P. C., and Schaper, F. (2001). Interleukin-6induced proliferation of pre-B cells mediated by receptor complexes lacking the SHP2/SOCS3 recruitment sites revisited. Eur. J. Biochem. 268,6401 .

Ge, W., Jiang, J., Arp, J., Liu, W., Garcia, B., and Wang, H. (2010). Regulatory T-cell generation and kidney allograft tolerance induced by mesenchymal stem cells associated with indoleamine 2,3-dioxygenase expression. Transplantation 90, 1312.

Ge, W., Jiang, J., Baroja, M. L., Arp, J., Zassoko, R., Liu, W., Bartholomew, A., Garcia, B., and Wang, H. (2009). Infusion of mesenchymal stem cells and rapamycin synergize to attenuate alloimmune responses and promote cardiac allograft tolerance. Am. J. Transplant. 9, 1760.

Hoogduijn, M. J., Crop, M. J., Korevaar, S. S., Peeters, A. M., Eijken, M., Maat, L. P., Balk, A. H., Weimar, W., and Baan, C. C. (2008). Susceptibility of human mesenchymal stem cells to tacrolimus, mycophenolic acid, and rapamycin. Transplantation 86 , 1283.

Lanzavecchia, A., Bernasconi, N., Traggiai, E., Ruprecht, C. R., Corti, D., and Sallusto, F. (2006). Understanding and making use of human memory B cells. Immunol. Rev. 211, 303 .

Le Texier, L., Thebault, P., Lavault, A., Usal, C., Merieau, E., Quillard, T., Charreau, B., Soulillou, J. P., Cuturi, M. C., Brouard, S., and Chiffoleau, E. (2011). Long-term allograft tolerance is characterized by the accumulation of B cells exhibiting an inhibited profile. Am. J. Transplant. 11, 429.
Liu, C., Noorchashm, H., Sutter, J. A., Naji, M., Prak, E. L., Boyer, J., Green, T., Rickels, M. R., Tomaszewski, J. E., Koeberlein, B., Wang, Z., Paessler, M. E., Velidedeoglu, E., Rostami, S. Y., Yu, M., Barker, C. F., and Naji, A. (2007). B lymphocytedirected immunotherapy promotes long-term islet allograft survival in nonhuman primates. Nat. Med. 13, 1295.

Liu, H., Lu, K., Macary, P. A., Wong, K. L., Heng, A., Cao, T., and Kemeny, D. M. (2012). Soluble molecules are key in maintaining the immunomodulatory activity of murine mesenchymal stromal cells. J. Cell. Sci. 125, 200.

Mauri, C., and Bosma, A. (2011). Immune regulatory function of $\mathrm{B}$ cells. Annu. Rev. Immunol. 30, 221.

Najar, M., Raicevic, G., Boufker, H. I., Fayyad Kazan, H., De Bruyn, C., Meuleman, N., Bron, D., Toungouz, M., and Lagneaux, L. (2010). Mesenchymal stromal cells use PGE2 to modulate activation and proliferation of lymphocyte subsets: tissue, Wharton's Jelly and bone marrow sources. Cell. Immunol. 264, 171.

Nauta, A. J., Westerhuis, G., Kruisselbrink, A. B., Lurvink, E. G. Willemze, R., and Fibbe, W. E. (2006). Donor-derived mesenchymal stem cells are immunogenic in an allogeneic host and stimulate donor graft rejection in a nonmyeloablative setting. Blood 108, 2114.

Newell, K. A., Asare, A., Kirk, A. D., Gisler, T. D., Bourcier, K., Suthanthiran, M., Burlingham, W. J., Marks, W. H., Sanz, I., Lechler, R. I., Hernandez-Fuentes, M. P., Turka, L. A., Seyfert-Margolis, V. L., and Immune Tolerance Network, S. T. S. G. (2010). Identification of a B cell signature associated with renal transplant tolerance in humans. J. Clin. Invest. 120, 1836.

Ng, Y. H., Oberbarnscheidt, M. H., Chandramoorthy, H. C., Hoffman, R., and Chalasani, G. (2010). B cells help alloreactive $\mathrm{T}$ cells differentiate into memory $\mathrm{T}$ cells. Am. J. Transplant. 10, 1970. combined comparison of adipose 
Rafei, M., Hsieh, J., Fortier, S., Li, M., Yuan, S., Birman, E., Forner, K., Boivin, M. N., Doody, K., Tremblay, M., Annabi, B., and Galipeau, J. (2008). Mesenchymal stromal cellderived CCL2 suppresses plasma cell immunoglobulin production via STAT3 inactivation and PAX5 induction. Blood 112, 4991.

Rasmusson, I., Le Blanc, K., Sundberg, B., and Ringden, O. (2007). Mesenchymal stem cells stimulate antibody secretion in human B cells. Scand. J. Immunol. 65, 336.

Redfield, R. R. III, Rodriguez, E., Parsons, R., Vivek, K., Mustafa, M. M., Noorchashm, H., and Naji, A. (2011). Essential role for B cells in transplantation tolerance. Curr. Opin. Immunol. 23, 685.

Reichardt, P., Dornbach, B., Rong, S., Beissert, S., Gueler, F., Loser, K., and Gunzer, M. (2007). Naive B cells generate regulatory $\mathrm{T}$ cells in the presence of a mature immunologic synapse. Blood 110, 1519.

Ren, G., Zhao, X., Zhang, L., Zhang, J., L'Huillier, A., Ling, W., Roberts, A. I., Le, A. D., Shi, S., Shao, C., and Shi, Y. (2010). Inflammatory cytokine-induced intercellular adhesion molecule-1 and vascular cell adhesion molecule-1 in mesenchymal stem cells are critical for immunosuppression. J. Immunol. 184, 2321.

Rocha, P. N., Butterly, D. W., Greenberg, A., Reddan, D. N., Tuttle-Newhall, J., Collins, B. H., Kuo, P. C., Reinsmoen, N., Fields, T., Howell, D. N., and Smith, S. R. (2003). Beneficial effect of plasmapheresis and intravenous immunoglobulin on renal allograft survival of patients with acute humoral rejection. Transplantation $75,1490$.

Roemeling-van Rhijn, M., Weimar, W., and Hoogduijn, M. J. (2012). Mesenchymal stem cells: application for solid-organ transplantation. Curr. Opin. Organ Transplant. 17, 55.

Sagoo, P., Perucha, E., Sawitzki, B., Tomiuk, S., Stephens, D. A., Miqueu, P., Chapman, S., Craciun, L., Sergeant, R., Brouard, S., Rovis, F., Jimenez, E., Ballow, A., Giral, M., Rebollo-Mesa, I., Le Moine,
A., Braudeau, C., Hilton, R., Gerstmayer, B., Bourcier, K., Sharif, A., Krajewska, M., Lord, G. M., Roberts, I., Goldman, M., Wood, K. J., Newell, K., Seyfert-Margolis, V., Warrens, A. N., Janssen, U., Volk, H. D., Soulillou, J. P., Hernandez-Fuentes, M. P., and Lechler, R. I. (2010). Development of a cross-platform biomarker signature to detect renal transplant tolerance in humans. J. Clin. Invest. 120,1848

Sbano, P., Cuccia, A., Mazzanti, B., Urbani, S., Giusti, B., Lapini, I., Rossi, L., Abbate, R., Marseglia, G., Nannetti, G., Torricelli, F., Miracco, C., Bosi, A., Fimiani, M., and Saccardi, R. (2008). Use of donor bone marrow mesenchymal stem cells for treatment of skin allograft rejection in a preclinical rat model. Arch. Dermatol. Res. 300, 115.

Schena, F., Gambini, C., Gregorio, A., Mosconi, M., Reverberi, D., Gattorno, M., Casazza, S., Uccelli, A. Moretta, L., Martini, A., and Traggiai, E. (2010). Interferon-gammadependent inhibition of B cell activation by bone marrow-derived mesenchymal stem cells in a murine model of systemic lupus erythematosus. Arthritis Rheum. 62, 2776.

Schu, S., Nosov, M., O’Flynn, L., Shaw, G., Treacy, O., Barry, F., Murphy, M., O'Brien, T., and Ritter, T. (2011). Immunogenicity of allogeneic mesenchymal stem cells. $J$. Cell. Mol. Med. doi: 10.1111/j.15824934.2011.01509.x. [Epub ahead of print].

Selmani, Z., Naji, A., Gaiffe, E., Obert, L., Tiberghien, P., Rouas-Freiss, N., Carosella, E. D., and Deschaseaux, F. (2009). HLA-G is a crucial immunosuppressive molecule secreted by adult human mesenchymal stem cells. Transplantation 87, $\mathrm{S} 62$.

Sioud, M. (2011). New insights into mesenchymal stromal cell-mediated T-cell suppression through galectins. Scand. J. Immunol. 73,79 .

Spaggiari, G. M., Abdelrazik, H., Becchetti, F., and Moretta, L. (2009). MSCs inhibit monocyte-derived DC maturation and function by selectively interfering with the generation of immature DCs: central role of MSC-derived prostaglandin E2. Blood 113, 6576.

Spaggiari, G. M., Capobianco, A., Abdelrazik, H., Becchetti, F., Mingari, M. C., and Moretta, L. (2008). Mesenchymal stem cells inhibit natural killer-cell proliferation, cytotoxicity, and cytokine production: role of indoleamine 2,3-dioxygenase and prostaglandin E2. Blood $111,1327$.

Sundin, M., Ringden, O., Sundberg, B., Nava, S., Gotherstrom, C., and Le Blanc, K. (2007). No alloantibodies against mesenchymal stromal cells, but presence of anti-fetal calf serum antibodies, after transplantation in allogeneic hematopoietic stem cell recipients, Haematologica 92, 1208.

Tabera, S., Perez-Simon, J. A., DiezCampelo, M., Sanchez-Abarca, L. I., Blanco, B., Lopez, A., Benito, A., Ocio, E., Sanchez-Guijo, F. M., Canizo, C., and San Miguel, J. F. (2008). The effect of mesenchymal stem cells on the viability, proliferation and differentiation of B-lymphocytes. Haematologica 93, 1301.

Tan, J., Wu, W., Xu, X., Liao, L., Zheng, F., Messinger, S., Sun, X., Chen, J., Yang, S., Cai, J., Gao, X., Pileggi, A., and Ricordi, C. (2012). Induction therapy with autologous mesenchymal stem cells in living-related kidney transplants: a randomized controlled trial. JAMA 307, 1169.

Traggiai, E., Volpi, S., Schena, F., Gattorno, M., Ferlito, F., Moretta, L., and Martini, A. (2008). Bone marrowderived mesenchymal stem cells induce both polyclonal expansion and differentiation of $\mathrm{B}$ cells isolated from healthy donors and systemic lupus erythematosus patients. Stem Cells 26, 562.

Tyden, G., Genberg, H., Tollemar J., Ekberg, H., Persson, N. H., Tufveson, G., Wadstrom, J., Gabel, M., and Mjornstedt, L. (2009). A randomized, doubleblind, placebocontrolled, study of single-dose rituximab as induction in renal transplantation. Transplantation 87, 1325 Walsh, R. C., Alloway, R. R., Girnita, A. L., and Woodle, E. S. (2012).
Proteasome inhibitor-based therapy for antibody-mediated rejection. Kidney Int. 81, 1067.

Xue, Q., Luan, X. Y., Gu, Y. Z., Wu, H. Y., Zhang, G. B., Yu, G. H., Zhu, H. T., Wang, M., Dong, W., Geng, Y. J., and Zhang, X. G. (2010). The negative co-signaling molecule b7$\mathrm{h} 4$ is expressed by human bone marrow-derived mesenchymal stem cells and mediates its T-cell modulatory activity. Stem Cells Dev. $19,27$.

Youd, M., Blickarz, C., Woodworth, L., Touzjian, T., Edling, A., Tedstone, J., Ruzek, M., Tubo, R., Kaplan, J., and Lodie, T. (2010). Allogeneic mesenchymal stem cells do not protect NZBxNZW F1 mice from developing lupus disease. Clin. Exp. Immunol. 161, 176.

Zhou, K., Zhang, H., Jin, O., Feng, X., Yao, G., Hou, Y., and Sun, L. (2008). Transplantation of human bone marrow mesenchymal stem cell ameliorates the autoimmune pathogenesis in MRL/lpr mice. Cell. Mol. Immunol. 5, 417.

Conflict of Interest Statement: The authors declare that the research was conducted in the absence of any commercial or financial relationships that could be construed as a potential conflict of interest.

Received: 02 April 2012; paper pending published: 18 April 2012; accepted: 01 July 2012; published online: 20 July 2012. Citation: Franquesa M, Hoogduijn MJ, Bestard $O$ and Grinyó JM (2012) Immunomodulatory effect of mesenchymal stem cells on B cells. Front. Immun. 3:212. doi: 10.3389/fimmu.2012.00212

This article was submitted to Frontiers in Alloimmunity and Transplantation, a specialty of Frontiers in Immunology. Copyright $\odot 2012$ Franquesa, Hoogduijn, Bestard and Grinyó. This is an openaccess article distributed under the terms of the Creative Commons Attribution License, which permits use, distribution and reproduction in other forums, provided the original authors and source are credited and subject to any copyright notices concerning any third-party graphics etc. 